\title{
Ensino Médio em São Paulo: a expansão das matrículas nos anos 1990
}

Ana Paula Corti

'Instituto Federal de Educação, Ciência e Tecnologia de São Paulo (IFSP),

São Paulo/SP - Brasil

RESUMO - Ensino Médio em São Paulo: a expansão das matrículas nos anos 1990. O artigo integra pesquisa sobre a expansão do Ensino Médio no estado de São Paulo, no período de 1991 a 2003. Justamente na década voltada à focalização das políticas no Ensino Fundamental, o Ensino Médio viveu o maior período do seu crescimento. São apresentados os dados acerca da evolução das matrículas nas quatro redes de ensino: estadual, particular, municipal e federal, bem como sua distribuição entre a Região Metropolitana e o Interior paulista. Também são apresentadas as matrículas por período, por série, e no ensino médio rural. Por fim, o texto aponta possibilidades de interpretação do fenômeno.

Palavras-chave: Ensino Médio. Ensino Público. Rede Estadual. Expansão Escolar.

ABSTRACT - Secondary Education in São Paulo: the expansion of enrollment in the 1990s. The article addresses the expansion of secondary education in the state of São Paulo, from 1991 to 2003. Exactly in the decade when the policies were focused on Elementary Education, Secondary Education had the longest period of growth. Data on the evolution of enrollment in the four school systems - state, private, municipal and federal - are presented, as well as its distribution across the metropolitan area and the interior of the state. Enrollment rates are also presented by period, by grade and in rural secondary education. Finally, the text points out possibilities of interpretation of the phenomenon.

Keywords: Secondary Education. Public Education. State School System. School Expansion.

Educação \& Realidade, Porto Alegre, v. 41, n. 1, p. 41-68, jan./mar. 2016. 41 http://dx.doi.org/10.1590/2175-623655996 
Nunca me esqueci da visão que tive da coroa do Camarote Real, no Teatro em Lisboa. De longe, uma maravilha.

Quando olhei por debaixo, repleta de sujeira, teias de aranha... e logo aprendi: Para conhecer as coisas, há que dar-lhes a volta. José Saramago

Este artigo integra pesquisa sobre a expansão do Ensino Médio na década de 1990, mais precisamente de 1991 a 2003, no estado de São Paulo. O crescimento das matrículas no ensino médio público foi intensificado na década de 1980, mas foi nos anos 1990 que ele atingiu seu ápice, produzindo a escola média massificada. Ocorre que os anos 1990 são conhecidos pela focalização das políticas no ensino fundamental, etapa para a qual convergiram os esforços governamentais, bem como a agenda da pesquisa educacional. Enquanto isso, justamente quando os olhares estavam voltados ao ensino fundamental, o ensino médio vivia o maior período do seu crescimento. Às sombras do ensino fundamental, o ensino médio foi sendo estendido a grupos sociais maiores e mais diversificados, que produziam novas formas de interação e de tensão com a cultura escolar estabelecida.

Os impactos deste processo foram enormes para as redes estaduais - sobre as quais recai a responsabilidade constitucional pela oferta que incorporaram em número crescente um grupo social relativamente novo - adolescentes e jovens - que por sua vez experimentavam mutações importantes nos processos de socialização num contexto de crise do Estado, das políticas sociais e do emprego, bem como mudanças no processo de individualização face as transformações das instituições tradicionais (escola, família, trabalho).

Muito embora a expansão do ensino médio tenha ocorrido sob forte protagonismo dos estados, são escassos os estudos sobre a expansão do ensino médio em âmbito estadual, sendo mais numerosos os estudos no nível nacional, que incidem principalmente sobre a legislação e as iniciativas reformistas, ou, nos anos 2000, sobre o ensino médio integrado ao ensino técnico ${ }^{1}$.

Do nosso ponto de vista, o foco estadual é importante, pois, os estados possuem autonomia na elaboração da política de ensino médio configurando um perfil de oferta escolar próprio. Na década de 1990, as políticas estaduais paulistas tiveram razoável protagonismo, antecipando modelos que foram defendidos posteriormente em âmbito nacional. Concorreu para isso a presença de técnicos e gestores paulistas em cargos estratégicos do MEC no governo Fernando Henrique Cardoso (1995 a 2002), na ocasião da implantação da Reforma Nacional do Ensino Médio. Isso mostra o quanto os trajetos da política educacional podem ser multidirecionais, sem haver, necessariamente, uma lógica linear de imposição das políticas nacionais sobre as políticas estaduais de educação. 


\section{A Expansão do Ensino Médio no Brasil e em São Paulo}

O processo de expansão do Ensino Médio no Brasil ganhou novo fôlego nos anos 1970. O então chamado ensino de $2^{\circ}$ grau ${ }^{2}$, por força da LDB 5692/1971, tornou-se uma etapa subsequente ao ensino de $1^{\circ}$ grau, sem os exames de admissão, que historicamente haviam sido os divisores de água entre o ensino primário e o ensino secundário ${ }^{3}$.

Na década de 1970 o país mais que dobrou suas matrículas no ensino médio, tendo registrado um aumento de 151,8\%, o que levou aos bancos escolares um contingente novo de 1 milhão e 700 mil alunos. Essa população ingressante foi, em grande medida, absorvida pela rede privada, que manteve uma participação expressiva na oferta das vagas, sendo responsável por 46,5\% das matrículas em 1980. A rede estadual não ampliou sua participação nas matrículas na década de 1970, pelo contrário, teve leve redução de 47,9\% em 1971 para 47\% em 1980.

Na década de 1980 o ritmo de expansão diminuiu, atingindo um crescimento de $33,8 \%$ nas matrículas. Porém, o perfil da oferta de ensino médio começou a se modificar. As redes estaduais ampliaram consideravelmente sua oferta, de modo que em 1991, atendiam a 65,5\% do total das matrículas do país. Maiores parcelas de alunos trabalhadores passaram a ter acesso ao ensino médio, geralmente no período noturno, no qual se concentravam mais da metade das matrículas.

A partir de 1990 o processo de expansão do Ensino Médio intensificou-se, gerando uma verdadeira explosão das matrículas, tornando-se a etapa da educação com maior crescimento na década. O movimento ascendente durou até 2004, quando o país atingiu o ápice de 9.169.357 matrículas. Entre 2005 e 2009 as matrículas diminuíram, e depois disso, estabilizaram-se. Nos anos 1990 o país viveu seu último surto de expansão de ensino médio, para iniciar um movimento de declínio e de estagnação nos anos 2000.

Quando focalizamos comparativamente o ritmo assumido pela expansão das matrículas de ensino médio no Brasil e no estado de São Paulo, observamos que, desde meados dos anos 1980 até 1995, a intensidade do crescimento das matrículas em São Paulo foi superior à média do país. Isso mudou a partir de 1996, quando as taxas paulistas diminuíram tornando-se menores do que a média nacional. Isso mostra que a expansão em São Paulo concentrou-se nos primeiros cinco anos da década de 1990, antecipando um crescimento que, no país, foi distribuído em toda a década. 
Tabela 1 - Taxa de crescimento matrículas Ensino Médio, Brasil e Estado de São Paulo (\%)

\begin{tabular}{|c|c|c|}
\hline & Brasil & São Paulo \\
\hline 1985 a 1990 & 16 & 23,2 \\
\hline 1991 a 1995 & 42,5 & 50,4 \\
\hline 1996 a 2000 & 42,7 & 24,3 \\
\hline 2001 a 2003 & 8 & 3,3 \\
\hline
\end{tabular}

Fonte: Censo Escolar e SEE-SP. Elaboração própria.

Gráfico 1 - Taxa de crescimento matrículas Ensino Médio, Brasil e Estado de São Paulo, (\%)

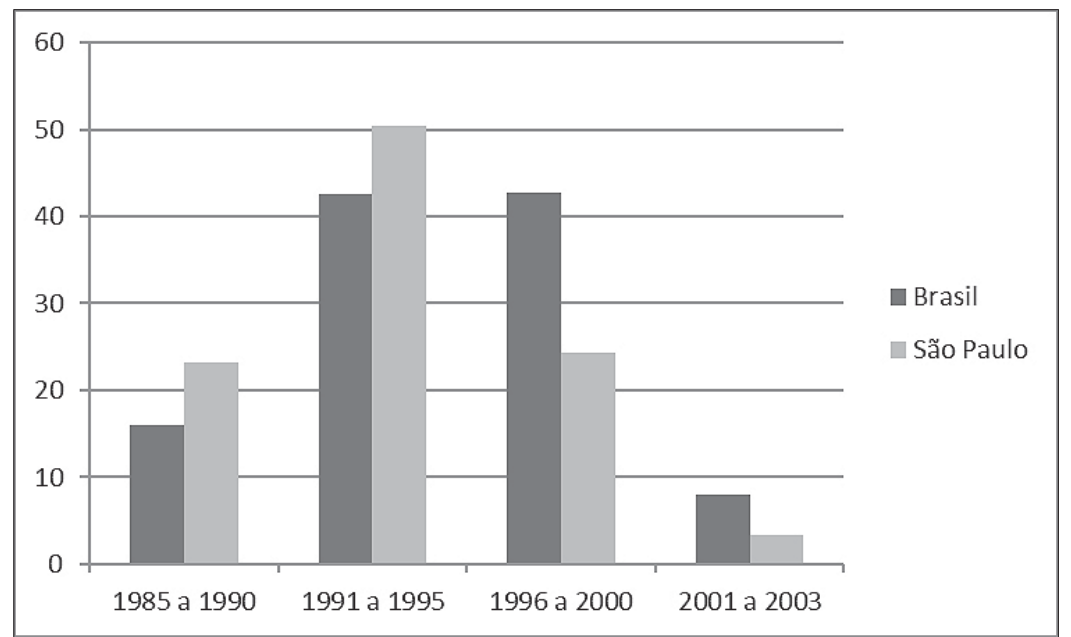

Fonte: Censo Escolar e SEE-SP. Elaboração própria.

\section{A Expansão das Matrículas no Estado de São Paulo}

Em 1930 o estado de São Paulo tinha três ginásios estaduais: um na capital e dois no interior. Cerca de setenta anos depois (entre $1930 \mathrm{e}$ 2000) eram contabilizados 2.703 estabelecimentos estaduais que ofertavam ensino médio.

Os ginásios foram expandidos no estado a partir de 1940 em função de dinâmicas políticas e eleitorais e de pressões populares pelo acesso à educação secundária (Sposito, 1984; Beisiegel, 2006). O secundário era formado pelo ciclo ginasial e ciclo colegial, e a abertura de turmas deste último estava condicionada à existência de turmas de ginásios nos estabelecimentos escolares. Assim, a expansão das escolas ginasiais em São Paulo criou as condições necessárias para a expansão do ciclo colegial, que possui um parentesco mais próximo com o atual ensino médio. 
Entre 1991 e 2003 o estado de São Paulo registrou um aumento de $96 \%$ nas matrículas de ensino médio. Isso significou o ingresso de $1 \mathrm{mi}-$ lhão de alunos no sistema escolar paulista. A partir de 2004 houve uma inflexão, e as matrículas começaram a declinar, revelando um esgotamento do processo de expansão. Esta movimentação das matrículas, ao longo dos últimos vinte e quatro anos, pode ser visualizada no gráfico abaixo:

Gráfico 2 - Evolução das matrículas de Ensino Médio, estado de São Paulo, todas as redes, 1991-2014

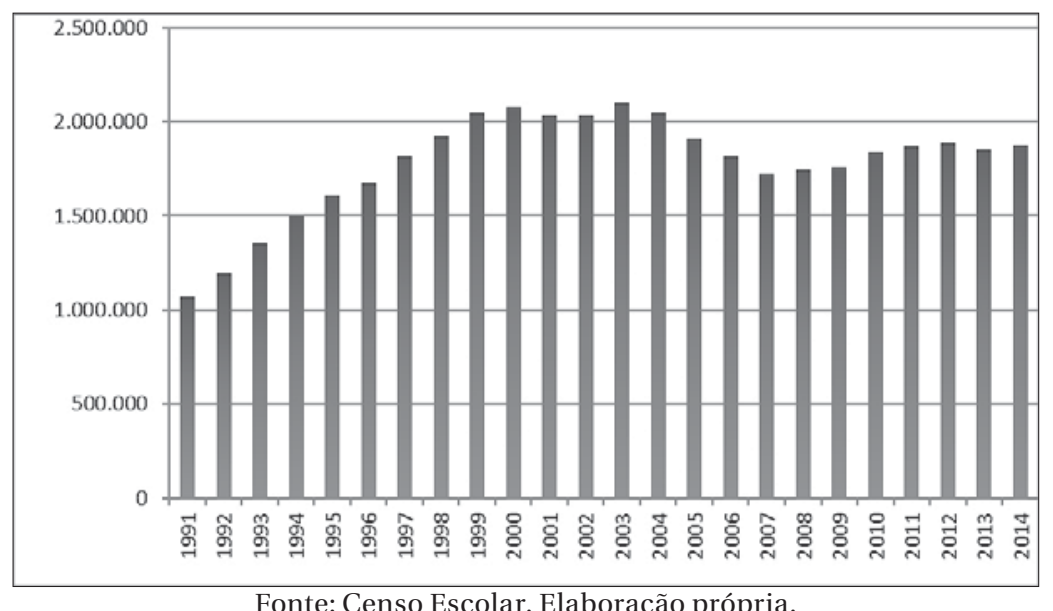

A oferta do ensino médio no estado de São Paulo é realizada por quatro redes de ensino: federal, municipal, estadual e particular. A rede de ensino estadual é caracterizada pela coexistência de redes mantidas e administradas por órgãos diferentes. Ela é formada, em sua maioria, por uma rede de escolas geridas pela Secretaria Estadual de Educação (rede SEE), mas também abrange uma rede de escolas de ensino técnico administradas pelo Centro Paula Souza, vinculada à Secretaria Estadual de Desenvolvimento, e uma terceira e menor rede de escolas mantidas pelas universidades estaduais paulistas (USP, Unicamp e Unesp). No Censo Escolar, é considerada rede estadual a somatória das redes acima mencionadas. Nos dados produzidos pela Secretaria Estadual de Educação é feita uma separação entre rede estadual SEE e outras, categoria que reúne as escolas do Centro Paula Souza e as administradas pelas universidades estaduais.

O crescimento das matrículas no ensino médio, em São Paulo, concentrou-se na rede administrada pela Secretaria Estadual de Educação (rede SEE). Esta rede, que já era responsável por $70 \%$ das matrículas em 1991, ampliou sua participação nos anos posteriores atingindo 85\% das matrículas em 2003. 
O setor privado, que teve enorme importância histórica na oferta de ensino médio no estado de São Paulo ${ }^{4}$, teve sua presença reduzida ao longo da década de 1990, contrariando algumas análises que indicavam uma tendência à expansão da escola privada no processo de modernização do ensino médio ${ }^{5}$ (Zibas, 1995; 1997). Mesmo num contexto de ajuste fiscal, redução dos gastos públicos, reforma do Estado com ênfase em seu papel regulador, o processo de expansão do ensino médio no estado de São Paulo foi protagonizado pelo setor estatal, através da oferta de vagas em escolas públicas gratuitas. Nesse sentido, é preciso destacar que o ciclo expansionista paulista foi também um ciclo de consolidação da oferta pública na educação de nível médio, seguindo tendência já observada no ensino fundamental.

A rede municipal tem baixa participação na oferta de vagas de ensino médio, inclusive em função da determinação constitucional que atribui aos municípios a responsabilidade prioritária pela oferta de educação infantil e ensino fundamental, vedando sua participação em outros níveis enquanto as demandas daquelas etapas não estiverem plenamente atendidas. Mas, considerando que a oferta de ensino médio está fora de sua competência constitucional, é significativo que as redes municipais ainda mantivessem, em 2003, cerca de 17 mil matrículas no ensino médio. Nesta rede observamos dois movimentos: um primeiro até 1995 foi de aumento da oferta de vagas, possivelmente impulsionado pela pressão da população diante da escassez de vagas na rede estadual; e um segundo movimento, a partir de 1996, de redução das matrículas. Há que se levar em conta na compreensão dessa redução, a intensificação da municipalização do ensino fundamental, e a implantação do FUNDEF- Fundo de Manutenção e Desenvolvimento do Ensino Fundamental e de Valorização do Magistério, que, supostamente, teria desestimulado ainda mais os municípios a investirem no ensino médio. Em termos gerais a tendência foi de redução do ensino médio nas redes municipais, passando de 21.263 matrículas em 1991 para 17.958 em 2003, o que representou uma mudança de $2 \%$ para $0,8 \%$ na participação desta rede no total.

A rede federal ${ }^{6}$ contava com três unidades no período analisado: a mais antiga, localizada na capital, e duas outras nas cidades de Cubatão e de Sertãozinho. Somadas, estas unidades ofereciam 4.254 vagas em 1997, número que declinou nos anos posteriores, chegando a 2.052 em 2003. A redução pode estar associada às modificações trazidas pelo Decreto Federal n. 2.208 de 1997, que tornou a educação profissional independente do ensino médio, podendo ser oferecida de forma concomitante ou sequencial a ele.

Muito embora participe de forma muito limitada do ponto de vista quantitativo, a rede federal ${ }^{7}$ ficou conhecida por seu prestígio na capital paulista, sendo muito disputada nos processos seletivos anuais na medida em que se tornou uma alternativa de ensino médio público de qualidade diante da precarização das escolas da rede pública estadual. 
Tabela 2 - Evolução das matrículas no Ensino Médio por dependência administrativa, estado de São Paulo, 1991-2003

\begin{tabular}{|c|c|c|c|c|c|c|c|}
\hline \multirow{2}{*}{ Ano } & \multicolumn{2}{c}{ Estadual } & Particular & $\begin{array}{c}\text { Muni- } \\
\text { cipal }\end{array}$ & Federal & Total \\
\cline { 2 - 8 } & SEE & Outras* & Total & & & & \\
\hline 1991 & 755.662 & 22.546 & 778.208 & 269.537 & 21.263 & 2.895 & 1.071 .903 \\
\hline 1992 & 895.192 & 24.233 & 919.425 & 246.460 & 23.435 & 3.873 & 1.193 .193 \\
\hline 1993 & 1.043 .220 & 25.802 & 1.069 .022 & 259.235 & 24.591 & 2.400 & 1.355 .248 \\
\hline 1994 & 1.110 .185 & 78.635 & 1.188 .820 & 284.316 & 26.703 & 3.241 & 1.503 .080 \\
\hline 1995 & 1.179 .297 & 78.916 & 1.258 .213 & 318.839 & 31.137 & 3.873 & 1.612 .062 \\
\hline 1996 & 1.242 .262 & 76.896 & 1.319 .158 & 320.290 & 33.538 & $* *$ & 1.672 .986 \\
\hline 1997 & 1.378 .321 & 74.066 & 1.452 .387 & 324.571 & 37.076 & 4.254 & 1.818 .288 \\
\hline 1998 & 1.529 .238 & 58.479 & 1.587 .717 & 297.065 & 33.485 & 3.625 & 1.921 .892 \\
\hline 1999 & 1.672 .915 & 47.259 & 1.720 .174 & 295.810 & 27.882 & 3.536 & 2.047 .402 \\
\hline 2000 & 1.739 .563 & 34.733 & 1.774 .296 & 280.843 & 20.896 & 3.106 & 2.079 .141 \\
\hline 2001 & 1.712 .931 & 26.959 & 1.739 .890 & 273.292 & 18.040 & 1.936 & 2.033 .158 \\
\hline 2002 & 1.750 .197 & 26.369 & 1.776 .566 & 269.261 & 17.446 & 1.997 & 2.065 .270 \\
\hline 2003 & 1.780 .465 & 26.945 & 1.807 .410 & 272.490 & 17.958 & 2.052 & 2.099 .910 \\
\hline
\end{tabular}

* Escolas mantidas e administradas por Universidades Estaduais Paulistas (USP, UNICAMP e UNESP), e pelo Centro Paula Souza, vinculado à Secretaria Estadual de Desenvolvimento. **Não informado no Censo Escolar. Rede estadual: dados fornecidos pela SEE-SP. Outras redes: Censo Escolar/ INEP. Elaboração própria

Gráfico 3 - Evolução da matrícula no Ensino Médio por dependência administrativa, estado de São Paulo, 1991-2003

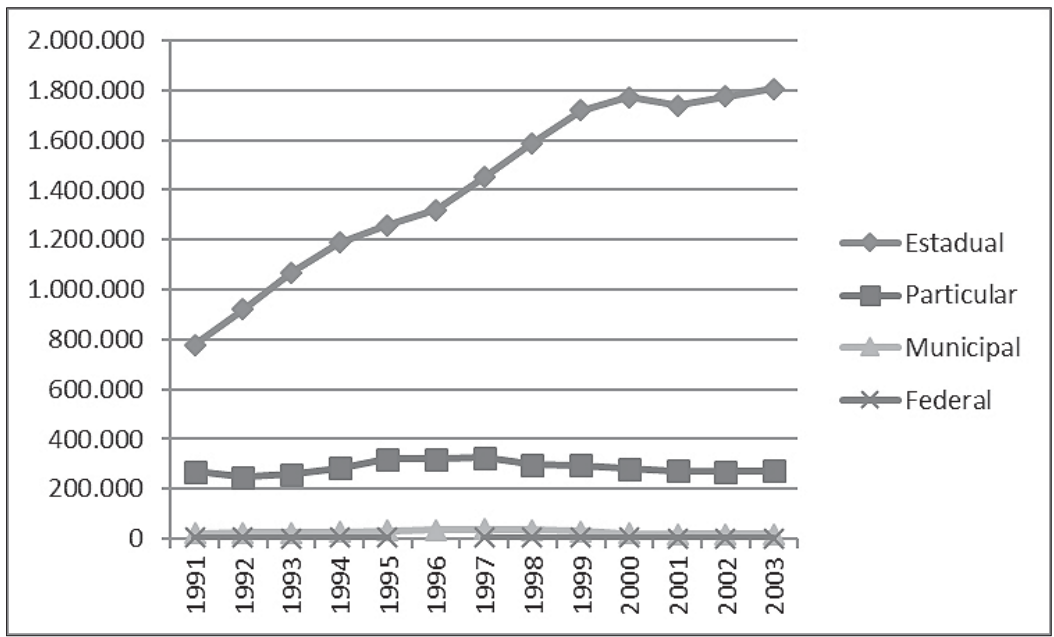


A tabela abaixo permite visualizar a taxa de participação de cada rede na oferta de ensino médio e revela o crescimento gradual da rede estadual, bem como o decréscimo da participação relativa de todas as outras redes, inclusive aquela de âmbito estadual mantida pelo Centro Paula Souza e pelas universidades estaduais paulistas, denominada de outras. Vemos que, ao lado da predominância da rede estadual mantida pela Secretaria de Educação, a segunda maior rede é a privada.

Tabela 3 - Evolução da taxa de participação nas matrículas de Ensino Médio por dependência administrativa, estado de São Paulo, 1991-2003 (\%)

\begin{tabular}{|c|c|c|c|c|c|c|c|}
\hline \multirow{2}{*}{ Ano } & \multicolumn{2}{|c|}{ Estadual } & \multirow{2}{*}{ Total } & Particular & Municipal & Federal & Total \\
\cline { 2 - 7 } & SEE & Outras & & & & \\
\hline 1991 & 70,5 & 2,1 & 72,6 & 25,2 & 2,0 & 0,2 & 100 \\
\hline 1992 & 75,0 & 2,1 & 77,1 & 20,6 & 2,0 & 0,3 & 100 \\
\hline 1993 & 77,0 & 1,9 & 78,9 & 19,1 & 1,8 & 0,2 & 100 \\
\hline 1994 & 73,9 & 5,2 & 79,1 & 18,9 & 1,8 & 0,2 & 100 \\
\hline 1995 & 73,2 & 4,9 & 78,1 & 19,8 & 1,9 & 0,2 & 100 \\
\hline 1996 & 74,3 & 4,6 & 78,9 & 19,1 & 2,0 & - & 100 \\
\hline 1997 & 75,8 & 4,1 & 79,9 & 17,9 & 2,0 & 0,2 & 100 \\
\hline 1998 & 79,6 & 3,0 & 82,6 & 15,5 & 1,7 & 0,2 & 100 \\
\hline 1999 & 81,7 & 2,3 & 84,0 & 14,4 & 1,4 & 0,1 & 100 \\
\hline 2000 & 83,7 & 1,7 & 85,4 & 13,5 & 1,0 & 0,1 & 100 \\
\hline 2001 & 84,2 & 1,3 & 85,5 & 13,5 & 0,9 & 0,1 & 100 \\
\hline 2002 & 84,8 & 1,3 & 86,1 & 13,0 & 0,8 & 0,1 & 100 \\
\hline 2003 & 84,8 & 1,3 & 86,1 & 13,0 & 0,8 & 0,1 & 100 \\
\hline
\end{tabular}

* Escolas mantidas e administradas por Universidades Estaduais Paulistas (USP UNICAMP e UNESP),epelo Centro Paula Souza, vinculado à Secretaria Estadual de Desenvolvimento. ${ }^{* *}$ Não informado no Censo Escolar. Rede estadual: dados fornecidos pela SEE-SP. Outras redes: Censo Escolar/ INEP. Elaboração própria.

O ritmo de crescimento do ensino médio foi mais forte na primeira metade da década de 1990: entre 1991 e 1995 o crescimento foi de $50,4 \%$, e de 1996 a 2000 foi de $24,3 \%$.

Em pouco mais de uma década a oferta pública estadual de ensino médio praticamente duplicou, e a explosão quantitativa delimitou os contornos de uma nova realidade escolar para a educação média no estado de São Paulo. 
Tabela 4 - Taxa de crescimento das matrículas no Ensino Médio por dependência administrativa, estado de São Paulo, 1991-2003 (\%)

\begin{tabular}{|c|c|c|c|c|c|}
\hline & Estadual & Particular & Municipal & Federal & Total \\
\hline 1991 a 1995 & 61,6 & 18,3 & 46,5 & 33,8 & 50,4 \\
\hline 1996 a 2000 & 34,5 & $(-) 12,3$ & $(-) 37,7$ & $(-) 27$ & 24,3 \\
\hline 2001 a 2003 & 3,8 & $(-) 0,3$ & $(-) 0,4$ & 6 & 3,3 \\
\hline
\end{tabular}

Fonte: SEE-SP. Elaboração Própria.

\section{As Matrículas no Interior e na Região Metropolitana}

Neste item vamos observar a distribuição territorial da expansão do Ensino Médio considerando a Região Metropolitana e o Interior paulista. No gráfico abaixo podemos verificar a movimentação da matrícula ao longo do período.

Gráfico 4 - Matrícula no Ensino Médio, estado de São Paulo, RMSP e Interior

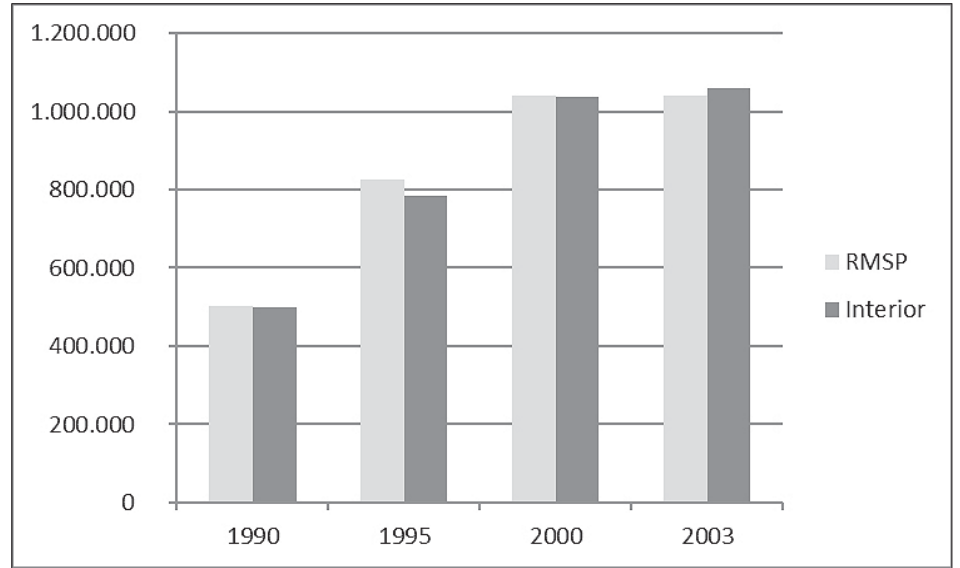

Fonte: SEE-SP. Elaboração própria.

A Região Metropolitana de São Paulo, formada por 38 municípios, respondia em 1991, por $47,7 \%$ da população paulista de 15 a 17 anos. O interior, formado por 534 municípios $^{8}$, respondia por 52,3\%. Estes percentuais permaneceram estáveis ao longo da década de 1990. A distribuição das matrículas foi bastante equilibrada entre a Região Metropolitana e o Interior, em todo o período. Na tabela abaixo podemos comparar os dados de população com os dados de matrícula, e notamos um discreto aumento na participação do interior paulista. 
Tabela 5 - Taxa de participação da população de 15 a 17 anos e das matrículas de Ensino Médio, estado de São Paulo, todas as redes, Região Metropolitana e Interior (\%)

\begin{tabular}{|c|c|c|c|c|}
\hline & \multicolumn{2}{|c|}{ RM } & \multicolumn{2}{c|}{ Interior } \\
\hline & População 15 a 17 & Matriculas & População 15 a 17 & Matriculas \\
\hline 1990 & 47,6 & 50,1 & 52,3 & 49,8 \\
\hline 2003 & 47,7 & 49,5 & 52,3 & 50,5 \\
\hline
\end{tabular}

Fonte: População- IBGE/ Fundação Seade. Matrículas- Censo Escolar. Elaboração própria.

Nas tabelas a seguir, temos as matrículas e taxas de participação relativa de cada rede na oferta do ensino médio, tanto na Região Metropolitana quanto no Interior. No início da década, a rede particular respondia por $31 \%$ das matrículas na Região Metropolitana e por $25 \%$ no Interior, números que declinaram ao longo dos anos. Inversamente, o Interior apresentava maior percentual de matrículas na rede pública em 1990 (74,5\%) contra 69\% na Região Metropolitana. Isso mostra que no início da década de 1990 a rede estadual tinha presença um pouco mais forte no Interior, e a rede particular, comparativamente, maior presença na Região Metropolitana, onde havia um mercado educacional mais dinâmico. Porém isso mudou ao longo da década. A rede privada diminuiu significativamente sua participação na Região Metropolitana, passando de $31 \%$ para $12,8 \%$. No Interior também houve redução, chegando à $13 \%$ de participação da rede privada, o mesmo percentual observado na Região Metropolitana. Quando observamos a tabela 6 vemos uma tendência a um padrão mais homogêneo de oferta de ensino médio na Região Metropolitana e do Interior paulista, considerando a participação das diversas redes de ensino.

Tabela 6 - Evolução das matrículas de Ensino Médio, estado de São Paulo, Região Metropolitana e Interior, por dependência administrativa

\begin{tabular}{|c|c|c|c|c|c|c|}
\hline & & & 1990 & 1995 & 2000 & 2003 \\
\hline \multirow[t]{7}{*}{ RMSP } & \multirow[t]{3}{*}{ Estadual } & SEE & 342.802 & 621.325 & 875.777 & 888.562 \\
\hline & & Outras & - & 27.596 & 12.191 & 8.246 \\
\hline & & Total & 342.802 & 648.921 & 887.968 & 896.808 \\
\hline & \multicolumn{2}{|l|}{ Municipal } & 3.794 & 7.829 & 6.818 & 7.916 \\
\hline & \multicolumn{2}{|l|}{ Particular } & 155.745 & 167.699 & 144.232 & 133.492 \\
\hline & \multicolumn{2}{|l|}{ Federal } & - & - & 2.010 & 1.203 \\
\hline & \multicolumn{2}{|l|}{ Total } & 502.341 & 824.449 & 1.041 .028 & 1.039 .419 \\
\hline \multirow[t]{3}{*}{ Interior } & \multirow[t]{3}{*}{ Estadual } & SEE & 356.066 & 557.972 & 863.786 & 891.903 \\
\hline & & Outras & - & 51.320 & 22.542 & 18.699 \\
\hline & & Total & 356.066 & 609.292 & 886.328 & 910.602 \\
\hline
\end{tabular}




\begin{tabular}{|c|c|c|c|c|c|}
\hline & Municipal & 16.081 & 23.308 & 14.078 & 10.042 \\
\cline { 2 - 6 } & Particular & 126.909 & 151.140 & 136.611 & 138.998 \\
\cline { 2 - 5 } & Federal & - & - & 1.096 & 849 \\
\cline { 2 - 6 } & Total & 499.056 & 783.740 & 1.038 .113 & 1.060 .491 \\
\hline
\end{tabular}

Fonte: SEE-SP. Elaboração própria. SEE - Escolas mantidas pela Secretaria de Educação. Outras - Conjunto de escolas estaduais mantidas e administradas pelas universidades estaduais paulistas - USP e pelo Centro Estadual de Educação Tecnológica 'Paula Souza', órgão vinculado à Secretaria Estadual de Desenvolvimento, além de outras Secretarias de Estado. Os dados da COGSP

- Coordenadoria de Ensino da Grande São Paulo correspondem à região metropolitana, com exceção de quatro Municípios da Grande São Paulo que estão incluídos na CEI: Arujá, Vargem Grande Paulista, Santa Isabel e Guararema. Os dados da CEI - Coordenadoria de Ensino do Interior, correspondem ao Interior.

Tabela 7 - Taxa de participação nas matrículas Ensino Médio, estado de São Paulo, Região Metropolitana e Interior, por dependência administrativa (\%)

\begin{tabular}{|c|c|c|c|c|c|c|}
\hline & & & 1990 & 1995 & 2000 & 2003 \\
\hline \multirow[t]{7}{*}{ RMSP } & \multirow[t]{3}{*}{ Estadual } & SE & 68,2 & 75,4 & 84,1 & 85,5 \\
\hline & & Outras & - & 3,3 & 1,2 & 0,8 \\
\hline & & Total & 68,2 & 78,7 & 85,3 & 86,3 \\
\hline & \multicolumn{2}{|l|}{ Municipal } & 0,8 & 0,9 & 0,7 & 0,8 \\
\hline & \multicolumn{2}{|l|}{ Particular } & 31,0 & 20,3 & 13,9 & 12,8 \\
\hline & \multicolumn{2}{|l|}{ Federal } & - & - & 0,2 & 0,1 \\
\hline & \multicolumn{2}{|l|}{ Total } & 100,0 & 100,0 & 100,0 & 100,0 \\
\hline \multirow[t]{7}{*}{ Interior } & \multirow[t]{3}{*}{ Estadual } & SE & 71,3 & 71,2 & 83,2 & 84,1 \\
\hline & & Outras & - & 6,5 & 2,2 & 1,8 \\
\hline & & Total & 71,3 & 77,7 & 85,4 & 85,9 \\
\hline & \multicolumn{2}{|l|}{ Municipal } & 3,2 & 3,0 & 1,4 & 0,9 \\
\hline & \multicolumn{2}{|l|}{ Particular } & 25,4 & 19,3 & 13,2 & 13,1 \\
\hline & \multicolumn{2}{|l|}{ Federal } & - & - & 0,1 & 0,1 \\
\hline & \multicolumn{2}{|l|}{ Total } & 100,0 & 100,0 & 100,0 & 100,0 \\
\hline
\end{tabular}

Fonte: SEE-SP. Elaboração própria. SEE - Escolas mantidas pela Secretaria de Educação. Outras - Conjunto de escolas estaduais mantidas e administradas pelas universidades estaduais paulistas - USP e pelo Centro Estadual de Educação Tecnológica 'Paula Souza', órgão vinculado à Secretaria Estadual de Desenvolvimento, além de outras Secretarias de Estado. Os dados da COGSP

- Coordenadoria de Ensino da Grande São Paulo correspondem à região metropolitana, com exceção de quatro Municípios da Grande São Paulo que estão incluídos na CEI: Arujá, Vargem Grande Paulista, Santa Isabel e Guararema. Os dados da CEI - Coordenadoria de Ensino do Interior, correspondem ao Interior. 


\section{Distribuição das Matrículas por Série}

A distribuição das matrículas nas três séries indica problemas de fluxo do ensino médio, com taxas de transição abaixo das que seriam esperadas numa situação ideal. Num fluxo perfeito os alunos matriculados na $1^{\text {a }}$ série, estariam, no ano seguinte, matriculados na $2^{\circ}$ série e assim por diante, o que geraria percentuais de matrícula equilibrados nas três séries. Entretanto não é isso que observamos. Há uma maioria de matrículas concentrada na $1^{\text {a }}$ série, e elas diminuem progressivamente na $2^{\mathrm{a}}$ e $3^{\mathrm{a}}$ séries, evidenciando a existência da repetência e do abandono escolar.

No intervalo entre 1995 e 2004 estas diferenças diminuíram, com tendência a um maior equilíbrio. Esta tendência foi resultado da diminuição do abandono e da reprovação ${ }^{9}$.

Entretanto foi um avanço que não atingiu as séries da mesma forma, pois o $2^{\circ}$ ano do ensino médio avançou menos do que o $3^{\circ}$ ano, o que pode sinalizar que a passagem do $1^{\circ}$ para $02^{\circ}$ ano é a mais problemática para os alunos, e uma vez que conseguem ultrapassar esta barreira, suas chances de prosseguirem no $3^{\circ}$ ano aumentam.

Tabela 8 - Evolução das Matrículas Ensino Médio, estado de São Paulo, todas as redes, por série

\begin{tabular}{|c|c|c|c|c|c|c|c|}
\hline \multirow{2}{*}{ Anos } & \multicolumn{2}{|c|}{$\mathbf{1}^{\mathbf{0}}$ ano } & \multicolumn{2}{c|}{$2^{\text {o }}$ ano } & \multicolumn{2}{c|}{$3^{\text {o }}$ ano } & \multirow{2}{*}{ Total } \\
\cline { 2 - 7 } & N. & $\%$ & N. & $\%$ & N. & \% & \\
\hline 1991 & 492.621 & 47,7 & 313.013 & 30,3 & 226.715 & 22 & 1.032 .349 \\
\hline 1992 & 547.306 & 48,2 & 343.166 & 30,2 & 244.688 & 21,5 & 1.135 .160 \\
\hline 1993 & 597.251 & 47,3 & 385.728 & 30,6 & 278.820 & 22,1 & 1.261 .799 \\
\hline 1994 & 652.249 & 46,5 & 433.365 & 30,9 & 317.176 & 22,6 & 1.402 .790 \\
\hline 1995 & 712.405 & 45,7 & 486.837 & 31,2 & 360.697 & 23,1 & 1.559 .939 \\
\hline 1996 & 731.959 & 45 & 511.897 & 31,5 & 383.166 & 23,5 & 1.627 .022 \\
\hline 1997 & 777.073 & 43,8 & 564.632 & 31,8 & 430.653 & 24,3 & 1.772 .358 \\
\hline 1998 & 740.127 & 39,4 & 641.434 & 34,1 & 496.265 & 26,4 & 1.877 .826 \\
\hline 1999 & 782.626 & 39,1 & 642.378 & 32,1 & 576.900 & 28,8 & 2.001 .904 \\
\hline 2000 & 803.920 & 39,4 & 664.034 & 32,5 & 573.304 & 28,1 & 2.041 .258 \\
\hline 2001 & 777.484 & 38,6 & 662.891 & 32,9 & 572.524 & 28,4 & 2.012 .899 \\
\hline 2002 & 794.189 & 38,7 & 670.763 & 32,7 & 586.082 & 28,6 & 2.051 .034 \\
\hline 2003 & 807.638 & 38,8 & 681.851 & 32,7 & 592.689 & 28,5 & 2.082 .178 \\
\hline 2004 & 761.359 & 37,4 & 679.121 & 33,4 & 593.687 & 29,2 & 2.034 .167 \\
\hline
\end{tabular}

Fonte: SEE-SP. Elaboração própria. 
Tabela 9 - Taxa de Reprovação e de Abandono Ensino Médio, Estado de São Paulo

\begin{tabular}{|c|c|c|}
\hline & Reprovação & Abandono \\
\hline 1991 & 11,4 & - \\
\hline 1994 & 13,2 & - \\
\hline 1996 & 9 & 12,9 \\
\hline 1998 & 4 & 8,7 \\
\hline 2000 & 6,7 & 10,4 \\
\hline 2002 & 8,5 & 7,3 \\
\hline
\end{tabular}

Fonte: Censo Escolar. Elaboração própria. Obs.: Até 1995 o Censo Escolar traz apenas o dado de reprovação, sem diferenciá-lo do abandono.

\section{Distribuição das Matrículas por Turno}

Passaremos agora a analisar a expansão do ponto de vista da sua distribuição nos diferentes turnos escolares. Os estudos de Beisiegel mostram que, a partir dos anos 1940 até 1960, a expansão dos ginásios estaduais em São Paulo, (que como dissemos, teve papel crucial na expansão do ciclo colegial e, posteriormente, no que hoje chamamos de ensino médio) ocorreu em grande medida a partir da abertura de cursos noturnos, o que ficou ainda mais evidenciado na capital paulista ${ }^{10}$. Mas como isso teria ocorrido no ensino médio?

A tabela abaixo mostra que o ensino médio cresceu consolidando e aprofundando aquilo que havia sido, décadas antes, uma estratégia emergencial de expansão dos ginásios em São Paulo: a abertura de cursos noturnos. Em 1995, de cada dez alunos matriculados no ensino médio, seis estudavam à noite, sendo que os cursos noturnos abrigavam mais de 1 milhão de estudantes, patamar que se manteve até $2001 \mathrm{em}$ números absolutos, e que mesmo declinando ainda permaneceu significativo até o último ano do ciclo expansionista, com mais de 900 mil matrículas. Os dados falam por si, revelando a centralidade dos cursos noturnos na estruturação da escola de ensino médio de massas nos anos 1990. 
Tabela 10 - Evolução das matrículas no Ensino Médio por turno, estado de São Paulo, todas as redes, 1991-2003

\begin{tabular}{|c|c|c|c|}
\hline Anos & Diurno & Noturno & Total \\
\hline 1991 & 387.925 & 683.993 & 1.071 .918 \\
\hline 1992 & 418.705 & 759.745 & 1.178 .450 \\
\hline 1993 & 463.186 & 881.643 & 1.344 .829 \\
\hline 1994 & 498.205 & 986.034 & 1.484 .239 \\
\hline 1995 & 544.533 & 1.067 .529 & 1.612 .062 \\
\hline 1996 & 618.848 & 1.054 .138 & 1.672 .986 \\
\hline 1997 & 695.900 & 1.122 .288 & 1.818 .188 \\
\hline 1998 & 769.991 & 1.151 .901 & 1.921 .892 \\
\hline 1999 & 1.230 .238 & 1.177 .164 & 2.407 .402 \\
\hline 2000 & 950.914 & 1.128 .227 & 2.079 .141 \\
\hline 2001 & 1.004 .130 & 1.029 .028 & 2.033 .158 \\
\hline 2002 & 1.086 .419 & 978.851 & 2.065 .270 \\
\hline 2003 & 1.171 .732 & 928.178 & 2.099 .910 \\
\hline
\end{tabular}

Fonte: Censo Escolar e SEE-SP. Elaboração própria.

Gráfico 5 - Taxa de participação das matrículas de Ensino Médio por turno, todas as redes, estado de São Paulo (\%)

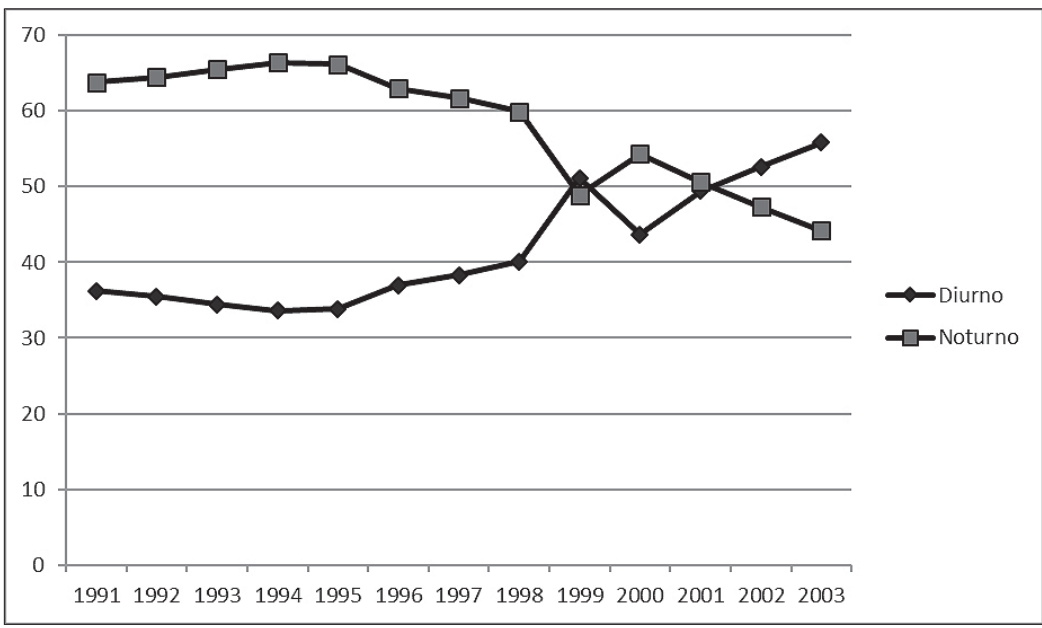

A importância dos cursos noturnos refletiu-se nas pesquisas em educação. Estado da arte coordenado por Marilia Sposito focalizando o período entre 1980 e 1998 (Sposito, 2002) contabilizou 40 pesquisas discentes de pós-graduação em educação, que elegeram o ensino noturno como tema principal, num total de 387 trabalhos. Corrochano e Nakano 
perceberam que 31 das 40 pesquisas foram realizadas entre 1990 e 1998 concluindo que "[...] o curso noturno é, sobretudo, um tema da década de 90" (Corrochano; Nakano, 2002, p. 101). As autoras identificaram algumas tendências nas pesquisas em termos das problemáticas investigadas:

1) investigar o sujeito que frequenta o ensino noturno, de modo geral o jovem que estuda e trabalha, trazendo à tona elementos que permitam identificar como veem, pensam, sentem e vivem experiências em torno da escola, do trabalho e das relações entre ambos; 2) chamar a atenção para problemas como o da inadequação dos cursos noturnos para os estudantes trabalhadores, evidenciando que a democratização do acesso não veio acompanhada de um ensino mais adequado aos interesses, necessidades e peculiaridades deste tipo de aluno; 3) finalmente, o do fracasso, manifesto através da evasão e da repetência, maiores no curso noturno do que no diurno (Corrochano; Nakano, 2002, p. 101).

Em estado da arte que deu continuidade ao mencionado, focalizando o período entre 1999-2006, constatou-se a diminuição do interesse dos pesquisadores pelo tema, já que foram identificados apenas 12 trabalhos, apesar do vertiginoso aumento no volume total da produção da pós-graduação (Peregrino, 2009).

A demanda por cursos noturnos de $2^{\circ}$ grau vinha sendo sentida desde a década de 1970 e $1980^{11}$, tanto assim que a Constituição de 1988 irá contemplá-la em seu artigo 208, inciso VI, em que o dever do Estado com a educação passa a ser efetivado, entre outras, pela oferta de ensino noturno regular, adequado às condições do educando.

O ensino noturno colocava-se como uma necessidade aos trabalhadores jovens e adultos dos bairros periféricos que queriam continuar seus estudos. Tendo em vista a preeminência do trabalho na vida deste segmento, o desafio era criar um espaço para que pudessem conciliar de algum modo sua condição trabalhadora com a frequência escolar. Esta tarefa não logrou muitos êxitos, a julgar pelo baixo índice de permanência e de aprovação destes alunos, e do baixo grau de aprendizado. Os estudantes entraram na escola noturna, mas sua permanência e aproveitamento não foram garantidos. De certa forma esta será uma das diferenças entre este período e a década de 1990, cujas políticas estaduais lograrão algum êxito mostrando avanço no desafio de fixar os alunos nas escolas (Peregrino, 2009), o que será apoiado, sobretudo na segunda metade da década, pela oferta de ensino médio na modalidade educação de jovens e adultos.

Ao serem consolidados, os cursos noturnos criaram uma nova divisão no interior da escola média, que desdobrava uma mesma unidade de ensino em duas: aquela que funcionava de dia, com alunos mais novos, com maior tempo para os estudos, e que apresentava melhor 
funcionamento com a presença de funcionários, professores e diretores, e a escola que funcionava à noite, que recebia alunos trabalhadores, de idades mais elevadas, cansados da jornada de trabalho diária, que muitas vezes apareciam atrasados e com fome, e eram recebidos por professores igualmente cansados da dupla jornada. Os professores, por sua vez, encontravam uma escola desprovida de pessoal administrativo e equipes de gestão.

A legitimidade do curso noturno pressupunha o reconhecimento da especificidade do estudante-trabalhador em relação aos outros estudantes, em nome do que se propunha um processo de compatibilização da escola, flexibilidade de horários e conteúdo curricular adaptado, uma demanda que buscava construir uma identidade própria e positiva para o ensino noturno, como uma modalidade legítima e importante para a efetivação da democratização educacional (Carvalho, 1998; Almeida, 1992)

Do ponto de vista da Secretaria de Educação, o ensino noturno era uma alternativa necessária diante da frágil infraestrutura física e financeira, sobretudo considerando que a expansão do ensino médio foi realizada sem financiamento próprio, utilizando os espaços do ensino fundamental.

A distribuição das matrículas por turno apresentou singularidades nas diversas redes escolares. Vê-se que a rede federal manteve uma situação estável, em que o diurno contabilizava pouco mais de $50 \%$ das matrículas. Na rede particular o ensino noturno foi menos significativo: em 1991 ele respondia por 43,7\% das matrículas, número que diminuiu progressivamente até atingir 11\% em 2003.

Assim, quando falamos em importância do ensino noturno estamos nos referindo, sobretudo, às redes públicas, e particularmente à estadual, em função da sua abrangência. A predominância do ensino noturno na oferta estadual de ensino médio começou a se modificar em 1996, quando se iniciou um crescimento da oferta de vagas no período diurno, inaugurando uma tendência que se manteve estável nos anos seguintes.

Esta mudança foi favorecida pela diminuição no ritmo da expansão das matrículas a partir de 1996. Mas há duas ações de política governamental que impactaram diretamente a mudança do padrão da oferta. A primeira e a mais importante delas foi a Reorganização física da rede estadual realizada em 1996, que estabeleceu uma ruptura com o modelo da escola de oito anos ${ }^{12}$, defendendo a separação dos alunos em quatro tipos de escola: 1) ciclo básico à $4^{\mathrm{a}}$ série; 2) $5^{\mathrm{a}}$ à $8^{\mathrm{a}}$ série; 3) $5^{\mathrm{a}}$ à $8^{\text {a }}$ série e ensino médio 4) ensino médio. Esta medida possibilitou ofertar ensino médio, prioritariamente, em escolas de $5^{\mathrm{a}}$ à $8^{\mathrm{a}}$ série, e sem as turmas de $1^{\text {a }}$ à $4^{\text {a }}$ séries, havia mais espaço para instalar turmas de ensino médio no período diurno. Mas, é necessário dizer que a medida também produziu a superlotação das salas de aula. A segunda ação go-

56 Educação \& Realidade, Porto Alegre, v. 41, n. 1, p. 41-68, jan./mar. 2016. 
vernamental foi o aumento na oferta de Ensino Médio na Modalidade EJA, que retirou do ensino médio regular boa parte dos alunos jovens e adultos, em geral trabalhadores, estudantes do noturno.

A partir de 2004, a diminuição no número de matrículas no ensino médio, em parte como efeito da dinâmica demográfica estadual que apresentou diminuição da população de 15 a 19 anos, favoreceu ainda mais este processo de transição para um ensino médio cada vez mais diurno.

Tabela 11 - Taxa de participação matrícula no Ensino Médio noturno por dependência administrativa, estado de São Paulo (\%)

\begin{tabular}{|c|c|c|c|c|}
\hline Anos & Estadual $^{*}$ & Municipal & Federal & Particular \\
\hline 1991 & 70,3 & 84,2 & - & 43,7 \\
\hline 1992 & 71,1 & 81,6 & - & 38,5 \\
\hline 1993 & 72,1 & 81,6 & - & 36 \\
\hline 1994 & 73,3 & 81,1 & 48,9 & 34 \\
\hline 1995 & 73,8 & 77,0 & - & 35,3 \\
\hline 1996 & 70 & 72,8 & 41,8 & 33,5 \\
\hline 1997 & 68,3 & 70,4 & 45,9 & 31,7 \\
\hline 1998 & 66,2 & 70,5 & 48,5 & 25,6 \\
\hline 1999 & 63,1 & 68,7 & 46,3 & 18,9 \\
\hline 2000 & 59,7 & 65,7 & - & 15,2 \\
\hline 2001 & 56 & 67,6 & - & 12,2 \\
\hline 2002 & 52,6 & 63,8 & - & 11,0 \\
\hline 2003 & 49 & 67,4 & - & \\
\hline
\end{tabular}

Fonte: SEE-SP e Censo Escolar. Elaboração própria.

*Rede SEE e outras; -Dado não localizado.

Não há grandes discrepâncias da oferta por turno na Região Metropolitana e no Interior. Entretanto, vale destacar que na intensa expansão dos primeiros cinco anos da década, a abertura de cursos noturnos foi uma estratégia importante, utilizada sobretudo na RM- o que pode ser percebido quando verificamos o percentual relativo do ensino noturno nas duas regiões. 
Ensino Médio em São Paulo

Tabela 12 -Taxa de Participação matrículas Ensino Médio por turno, todas as redes, estado de São Paulo, Região Metropolitana e Interior (\%)

\begin{tabular}{|c|c|c|c|c|c|c|}
\cline { 2 - 7 } \multicolumn{1}{c|}{} & \multicolumn{3}{c|}{ RMSP } & \multicolumn{3}{c|}{ Interior } \\
\hline Ano & Diurno & Noturno & Total & Diurno & Noturno & Total \\
\hline 1990 & 36,1 & 63,9 & 100,0 & 34,4 & 65,6 & 100,0 \\
\hline 1995 & 31,7 & 68,3 & 100,0 & 35,9 & 64,1 & 100,0 \\
\hline 2000 & 42,7 & 57,3 & 100,0 & 49,0 & 51,0 & 100,0 \\
\hline 2003 & 52,9 & 47,1 & 100,0 & 58,8 & 41,2 & 100,0 \\
\hline
\end{tabular}

Fonte: SEE-SP. Elaboração própria.

Mas será que a mudança no padrão da oferta atingiu todas as séries do ensino médio de forma homogênea? A tabela abaixo é bastante reveladora e mostra que, até 1996, havia uma distribuição muito equilibrada das matrículas nas três séries do ensino médio noturno, situação que se modifica a partir de então, com uma diminuição mais significativa do noturno no $1^{\circ}$ ano. No intervalo entre 1995 e 2004 houve uma diminuição de $34,1 \%$ nas matrículas do $1^{\circ}$ ano à noite, bem diferente da situação do $2^{\circ}$ ano que teve redução de $23 \%$, e do $3^{\circ}$ ano que teve redução de apenas $13,9 \%$. Assim, apesar da tendência geral de transição das matrículas para o período diurno, o $2^{\circ} \mathrm{e}$, sobretudo, o $3^{\circ}$ ano do ensino médio continuam a apresentar altos percentuais de matrícula no período noturno. Isso decorre do critério etário utilizado pela Secretaria de Educação, em que se prioriza a oferta de turmas para os alunos mais novos no período diurno. Os alunos de terceiro ano do ensino médio são os mais velhos, comparativamente, razão pela qual a oferta concentra-se à noite, diante da falta de espaços durante o dia. Além das condições da oferta, há também as características da demanda escolar. Uma parte significativa dos jovens e adultos matriculados no ensino médio são trabalhadores e buscam o turno da noite como forma de conciliar estudo e trabalho.

Tabela 13 - Taxa de participação matrículas no Ensino Médio Noturno por série, todas as redes, estado de São Paulo (\%)

\begin{tabular}{|c|c|c|c|c|}
\hline \multirow{2}{*}{ Anos } & \multirow{2}{*}{$\begin{array}{c}\text { Total } \\
\text { Noturno }\end{array}$} & \multicolumn{3}{|c|}{ Noturno } \\
\cline { 3 - 5 } & & 1a Série & 2 $^{\text {a }}$ Série & 3a Série \\
\hline 1991 & 63,8 & 63,8 & 64,5 & 63,5 \\
\hline 1992 & 64,5 & 65,6 & 64,2 & 63,5 \\
\hline 1993 & 65,5 & 67,1 & 65,6 & 63,8 \\
\hline 1994 & 66,4 & 67 & 67,4 & 65,9 \\
\hline 1995 & 66,2 & 66,1 & 67,3 & 66,6 \\
\hline 1996 & 63 & 60,6 & 65,1 & 66,2 \\
\hline
\end{tabular}




\begin{tabular}{|c|c|c|c|c|}
\hline 1997 & 61,7 & 59,2 & 62,9 & 65,9 \\
\hline 1998 & 59,9 & 55 & 62,1 & 64,9 \\
\hline 1999 & 57,5 & 51,8 & 59,3 & 64,2 \\
\hline 2000 & 54,3 & 47,7 & 56,5 & 61,5 \\
\hline 2001 & 50,6 & 43,2 & 52,3 & 56,6 \\
\hline 2002 & 47,4 & 39,3 & 49,5 & 56,5 \\
\hline 2003 & 44,2 & 36 & 46,6 & 54,3 \\
\hline 2004 & 42 & 32 & 44,3 & 52,7 \\
\hline \multicolumn{5}{|c}{ Fonte: Censo Escolar. Elaboração própria. } \\
\hline
\end{tabular}

\section{As Matrículas no Ensino Médio Rural}

Coerente com o forte processo de urbanização do estado de São Paulo, a expansão das matrículas no ensino médio foi concentrada nas áreas urbanas. No início da década de 1990, contabilizavam-se 2,2 milhões de habitantes nas áreas rurais do estado (7,2\%) e 29,3 milhões nas áreas urbanas (92,8\%). Em 1991 cerca de 73 mil jovens entre 15 e 19 anos moravam no campo ( $27,8 \%$ do total na faixa etária).

Tendo em vista o tamanho da população jovem no campo, percebemos que o número de matrículas fica muito aquém. Mas também se nota, entre 1991 e 2003, um aumento no número absoluto de matrículas, que passa de 6.665 em 1991 para 13.972 em 2003, um crescimento de $109,6 \%$ no período. Houve flutuações com diminuição do ensino médio no campo a partir de 1997, redução que foi expressiva entre 1997 e 1998 quando foram perdidas mais de 2,5 mil matrículas. No início dos anos 2000 o crescimento nas matrículas é retomado.

Em consonância com o ensino médio regular e na modalidade EJA, também no ensino médio rural a rede estadual aparece como a principal provedora das vagas, um papel que foi sendo ampliado até alcançar 90,8\% do total das matrículas em 2003. Di Pierro e Andrade apontam que nos anos 2000 houve uma diminuição do número de escolas e de matrículas no campo, considerando-se todas as etapas, níveis e modalidades da educação básica. Apontam que a presença de jovens moradores de áreas rurais no sistema escolar é maior do que as vagas ofertadas pela educação no campo, o que sugere um processo de urbanização da escolarização desta população, baseado em iniciativas de transporte escolar e nucleação (Di Pierro; Andrade, 2009). 
Tabela 14 - Evolução das matrículas Ensino Médio Rural, por dependência administrativa, estado de São Paulo, 1991-2003

\begin{tabular}{|c|c|c|c|c|c|c|c|}
\hline \multirow{2}{*}{ Anos } & \multirow{2}{*}{ Total } & \multicolumn{2}{|c|}{ Estadual } & \multicolumn{2}{c|}{ Municipal } & \multicolumn{2}{c|}{ Particular } \\
\cline { 3 - 8 } & & $\mathbf{N .}$ & $\mathbf{\%}$ & $\mathbf{N}$. & $\mathbf{\%}$ & $\mathbf{N}$. & \% \\
\hline 1991 & 6.665 & 5.153 & 77,3 & 0 & 0 & 1.512 & 22,7 \\
\hline 1997 & 10.466 & 8.737 & 84,1 & 0 & 0 & 1.645 & 15,7 \\
\hline 1998 & 7.774 & 7.351 & 94,5 & 54 & 0,6 & 369 & 4,7 \\
\hline 1999 & 8.781 & 7.006 & 79,8 & 56 & 0,6 & 1.719 & 19,6 \\
\hline 2000 & 7.879 & 6.833 & 86,7 & 61 & 0,7 & 985 & 12,5 \\
\hline 2001 & 8.017 & 6.954 & 86,7 & 100 & 1,2 & 963 & 12 \\
\hline 2002 & 9.839 & 9.181 & 93,3 & 132 & 1,3 & 526 & 5,3 \\
\hline 2003 & 13.972 & 12.692 & 90,8 & 415 & 2,9 & 865 & 6,2 \\
\hline
\end{tabular}

Fonte: Censo Escolar. Elaboração própria.

No período de 1992 a 1996 as Sinopses do Censo Escolar não informam as matrículas no Ensino Médio rural.

Obs.: A rede federal não oferece matrículas no ensino médio rural.

\section{Evolução das Taxas de Escolarização}

Vamos agora observar a expansão do ponto de vista da cobertura escolar em relação à população. Um dos indicadores que nos ajuda a visualizar a cobertura na sua relação com a idade ideal dos alunos é a taxa líquida de escolarização. Ela consiste na razão entre os matriculados numa determinada etapa escolar na faixa etária considerada ideal para ela, e a população total nessa mesma faixa etária. Dada a forte inter-relação entre o ensino fundamental e o ensino médio, vamos observar as taxas líquidas em ambas as etapas de ensino.

A taxa líquida do ensino fundamental paulista já era alta em 1980, talvez por isso tenha aumentado em ritmo mais lento, crescendo apenas 5\% na década de 1990. Em 2003, observamos uma cobertura próxima dos $100 \%$ em São Paulo, o que significa que praticamente todas as crianças estavam sendo atendidas no ensino fundamental na idade ideal.

Tabela 15 - Evolução da Taxa Líquida de Escolarização no Ensino Fundamental, todas as redes, estado de São Paulo, 1980-2003

\begin{tabular}{|c|c|}
\hline Ano & Tx. Escolarização Líquida no EF \\
\hline 1980 & 90 \\
\hline 1991 & 92,5 \\
\hline 1994 & 95,4 \\
\hline 1998 & 98,2 \\
\hline 2000 & 97,3 \\
\hline 2003 & 99,5 \\
\hline
\end{tabular}

Fonte: MEC/INEP/Censo Escolar. Edudata Brasil; IBGE, Censo Demográfico. 
Ao focalizar o Ensino Médio no estado de São Paulo encontramos uma realidade bem diferente. As taxas eram baixas em 1980 e ao longo desta década ficaram estagnadas. A situação melhorou significativamente nos anos 1990, com um crescimento de $30 \%$ na taxa líquida de escolarização. Podemos afirmar que o estado deu um verdadeiro salto no atendimento aos adolescentes no ensino médio em idade adequada. Alguns fatores podem ter concorrido para isso: a melhoria no fluxo do ensino fundamental na década de 1980, a melhoria no fluxo do ensino médio ao longo dos anos 1990 (com diminuição do abandono e da reprovação), e aumento da permanência dos alunos nos sistemas de ensino na transição entre o ensino fundamental e o ensino médio ${ }^{13}$. O segundo fator, a melhoria no fluxo do ensino médio, foi intensificado a partir de 1995 quando foram implantadas medidas de estímulo à aprovação.

Tabela 16 - Evolução da Taxa Líquida de Escolarização no Ensino Médio, todas as redes, estado de São Paulo, 1980-2003

\begin{tabular}{|c|c|}
\hline Ano & Tx. Escolarização Líquida no EM \\
\hline 1980 & 24,1 \\
\hline 1991 & 24,1 \\
\hline 1994 & 33,1 \\
\hline 1998 & 51,9 \\
\hline 2000 & 54,7 \\
\hline 2003 & 62,8 \\
\hline
\end{tabular}

Fonte: MEC/INEP/Censo Escolar. Edudata Brasil; IBGE, Censo Demográfico.

Os dados sugerem que a correção de fluxo no ensino fundamental paulista, um dos fatores que favoreceu a expansão das matrículas no $\mathrm{EM}$, foi anterior à adoção das ações governamentais, indicando que os impactos das políticas de governo são, possivelmente, menores do que uma parte da literatura costuma considerar. Nesse sentido, concordamos com a análise feita por Oliveira (2007, p. 673) a respeito da relação entre a expansão educacional e as ações governamentais.

[...] a ação de expansão da matrícula constitui processo sistêmico de longo prazo. A ação dos governos tem relativamente pouco impacto em sua dinâmica. Encontramos aqui outra evidência do argumento de fundo que estamos construindo. A ação dos diferentes governos nesse particular é condicionada por um processo social mais amplo e sob o qual eles têm capacidade limitada de agir, positiva ou negativamente.

\section{Concluintes no Ensino Fundamental e no Ensino Médio}

Um fator importante que atua como condicionante para a expansão do ensino médio são as taxas de conclusão do ensino fundamental. 
Quanto maior for o número de pessoas com ensino fundamental completo, maior será a demanda potencial para o Ensino Médio.

Tanto no Brasil quanto no estado de São Paulo houve um enorme avanço no número de concluintes do ensino fundamental na década de 1990. Em São Paulo houve um aumento de $117 \%$ entre 1991 e 2000. O crescimento no número de pessoas formadas no Ensino Fundamental foi mais intenso entre 1991 e 1995, movimento que foi acompanhado por um ritmo também maior de aumento de matrículas no EM.

Tabela 17 - Taxa de crescimento dos concluintes no Ensino Fundamental, e taxa de crescimento das matrículas no Ensino Médio, estado de São Paulo, todas as redes (\%)

\begin{tabular}{|c|c|c|}
\hline & Tx. Crescim. Concluintes EF & Tx. Crescim. Matrículas EM \\
\hline 1991 a 1995 & 72,4 & 50,4 \\
\hline 1996 a 2000 & 17 & 24,3 \\
\hline 2001 a 2003 & 7,4 & 3,3 \\
\hline
\end{tabular}

E o que dizer dos concluintes do Ensino Médio? Os dados revelam que, no estado, houve aumento substancial dos concluintes até 1998, e, depois, diminuição. Ainda assim, chegamos em 2003 com um número quase $100 \%$ maior de alunos que concluíam o Ensino Médio, em comparação com 1991.

Tabela 18 - Concluintes Ensino Médio, Estado de São Paulo

\begin{tabular}{|c|c|}
\hline & Concluintes Ensino Médio \\
\hline 1991 & 241.018 \\
\hline 1994 & 357.318 \\
\hline 1996 & 479.920 \\
\hline 1998 & 520.923 \\
\hline 2000 & 507.995 \\
\hline 2003 & 479.432 \\
\hline
\end{tabular}

Fonte: Censo Escolar. Elaboração própria. 
Gráfico 6 - Concluintes Ensino Médio, estado de São Paulo

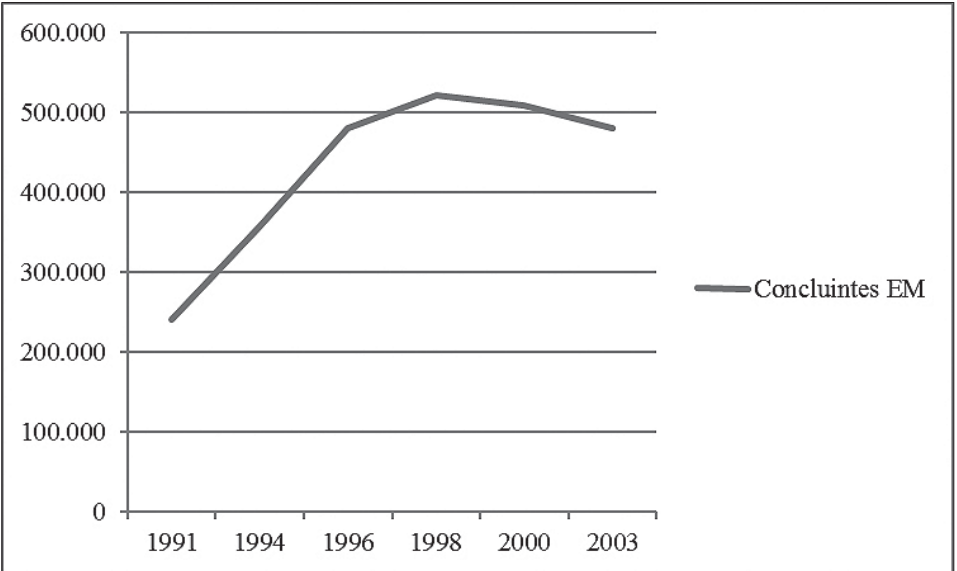

\section{Considerações Finais}

Podemos analisar a expansão das matrículas em dois momentos distintos: 1991 a 1995 e 1996 a 2003. O crescimento das matrículas foi mais intenso entre 1991 e 1995, justamente nos anos de acentuada crise econômica e superinflação. O número de concluintes do ensino fundamental apresentou crescimento de $72 \%$, gerando enorme pressão sobre o ensino médio, fruto de uma correção de fluxo que vinha crescendo nos anos 1980. A questão demográfica teve grande importância, pois na década de 1990 o país, e o estado de São Paulo, viveram a chamada onda jovem $^{14}$, um aumento absoluto no número de jovens, principalmente na faixa dos 15 aos 19 anos. Esta situação gerou escassez de vagas de ensino médio na rede estadual. A secretaria de educação orientou oficialmente sua rede a priorizar a matrícula no ensino fundamental, e adotou uma política de contenção de vagas na educação de jovens e adultos. Nada disso impediu a enorme explosão nas matrículas de Ensino Médio. A demanda foi sendo acomodada precariamente em escolas organizadas para receber prioritariamente alunos de ensino fundamental, preferencialmente à noite. Em 1995 verificou-se o ápice do ensino médio noturno em São Paulo, quando era responsável por $74 \%$ das matrículas. O ensino médio regular era formado por adolescentes, jovens e adultos, estudantes do período noturno.

A partir de 1995 o ensino médio começou a se modificar, com o aumento da oferta pública no período diurno e aumento nas taxas líquidas de escolarização. Isso foi modificando a cara do ensino médio, que foi se tornando cada vez mais uma escola de adolescentes. Duas ações de governo foram especialmente importantes para imprimir este novo rumo: 1) a reorganização da rede física e 2) ampliação da oferta de EJA Ensino Médio. Muito embora não tenham se apresentado, e nem tenham sido reconhecidas pela pesquisa educacional como Políticas para 
o Ensino Médio, foram ações que impactaram a realidade desta etapa. A reorganização da rede física abriu mais espaços nas escolas para a instalação de turmas diurnas, e a ampliação da oferta de EJA possibilitou deslocar o aluno mais velho, trabalhador, do ensino médio regular, resultando em diminuição da distorção idade-série deste último, e colaborando para o rejuvenescimento da EJA que passou a receber muitos alunos jovens e jovens-adultos.

A partir de 1996 houve uma política educacional sistêmica, e ações de correção de fluxo mais contundentes, tais como a adoção dos ciclos no ensino fundamental ${ }^{15}$, e implantação da progressão continuada. Entretanto, o grosso da expansão do ensino médio já tinha ocorrido. Não se pode afirmar que a oferta se organizou sob melhores condições ou com maior qualidade, se comparada com os primeiros cinco anos da década, mas é possível afirmar que o padrão da ação do poder público se modificou. Beisiegel, ao analisar a ampliação do ensino secundário nas décadas de 1940 a 1960 aponta que:

\begin{abstract}
A princípio, é o interesse político-eleitoral de candidatos às posições eletivas que estabelece os canais que relacionam as aspirações educacionais da população e a ação do poder público estadual. Depois, postulado o atendimento de todos, os mecanismos e agentes deste relacionamento entre a evolução da procura e a expansão da oferta e vagas passam a ser outros: é a administração do sistema escolar que elabora instrumentos de estimação antecipada das dimensões de procura e que se encarrega de atuar no sentido da criação de condições materiais e funcionais necessárias ao atendimento de todos os candidatos (Beisiegel, 2004, p. 39).
\end{abstract}

Esta situação descrita em relação à expansão, sobretudo, do ensino ginasial, encontra ressonância no processo de expansão do ensino médio nos anos 1990. Inspirados pela análise de Beisiegel, podemos afirmar que até meados dos anos 1990 a demanda popular por ensino médio invadiu a escola pública, a despeito da ausência de uma ação organizada do Estado, e até mesmo a despeito de sua política de priorização do ensino fundamental. Muitas improvisações foram necessárias, bem como o aproveitamento intenso do período noturno. A disputa por vagas foi acirrada e envolvia vestibulinhos, filas na porta das escolas, sorteios e muita confusão ${ }^{16}$.

Os elementos irracionais da expansão foram cedendo cada vez mais espaço para um controle burocrático. Como aponta Weber, a burocracia

[...] desenvolve sua peculiaridade específica, bem-vinda ao capitalismo, com tanto maior perfeição quanto mais se 'desumaniza', vale dizer, quanto mais perfeitamente consegue realizar aquela qualidade específica que é louvada como sua virtude: a eliminação do amor, do ódio e 
de todos os elementos sentimentais, puramente pessoais e, de modo geral, irracionais, que se subtraem ao cálculo, na execução das tarefas oficiais (Weber, 1999, p. 213).

A partir de 1996 o Estado tomou para si a planificação sistêmica da oferta de vagas, por meio da reorganização da rede física, do cadastro informatizado dos alunos e da matrícula automática. Por um lado, a oferta de ensino médio passou a ser mais racionalizada e controlada pelo Estado, equilibrando oferta e procura de vagas. Por outro lado, houve superlotação de salas de aula e diminuição na autonomia das unidades escolares, que perderam a prerrogativa de decidir o método pelo qual a população teria acesso às suas vagas. Os familiares e alunos também perderam a possibilidade de escolher a escola em que iriam estudar.

É possível que a forte expansão do ensino médio tenha incluído esta etapa no patamar mínimo de escolaridade exigido para todos. Como mais um dever do cidadão, a escolarização tende a se reverter em técnica social (Beisiegel, 2004) a serviço do processo de modernização do país. Parece haver uma lógica de racionalidade presente na expansão de sistemas de educação observada nos mais variados países e em temporalidades distintas, e que funciona como uma tendência pesada, uma expressão usada por Fanfani (2007).

A escolarização em massa é uma das facetas do processo de modernização, uma espécie de moto perpétuo cuja dinâmica parece, em alguma altura, autonomizar meios e fins. Nesse sentido, o quanto a expansão do ensino médio conseguiu atingir finalidades humanamente válidas, ligadas aos processos de emancipação e realização das potencialidades dos indivíduos, permanece ainda uma questão em aberto.

Recebido em 28 de maio de 2015 Aprovado em 16 de dezembro de 2015

\section{Notas}

1 A esse respeito ver a pesquisa "Estado da Arte da Produção Acadêmica sobre Ensino Médio no Brasil - Período de 1998 a 2008”, coordenada por Maria Margarida Machado, no âmbito da Universidade Federal de Goiás - UFG.

2 No período aqui analisado foram duas as nomenclaturas oficiais utilizadas: $2^{\circ}$ grau, até 1995, e Ensino Médio, a partir de 1996. Entretanto, vamos nos referir sempre a ensino médio, para uniformizar a linguagem, facilitando a compreensão.

3 Para entender as definições de ensino primário e secundário, e as variações das nomenclaturas remeto aos trabalhos de Beisiegel (2004; 2006), Romanelli (1997) e Pinto (2002).

4 Em 1940 os estabelecimentos de ensino particulares eram responsáveis por $75,2 \%$ das matrículas no ensino médio no estado de São Paulo, e em 1960, sua participação foi de $43,2 \%$, contando com uma rede de 310 escolas das quais 133 eram mantidas por instituições católicas (Beisiegel, 2006).

Educação \& Realidade, Porto Alegre, v. 41, n. 1, p. 41-68, jan./mar. 2016. 
5 Mas isso não significa que a lógica empresarial privada tenha ficado ausente da educação básica nos anos 1990. Sua presença se fez sentir de formas mais indiretas, induzidas num contexto político de retração do estado e flexibilização nas relações de trabalho. Estamos nos referindo a medidas como a terceirização de serviços nas escolas públicas (limpeza, alimentação entre outros), e a venda privada de pacotes e materiais pedagógicos para redes escolares, além da flexibilização nos contratos de trabalho dos professores, possibilitada pela nova legislação trabalhista aprovada em 1998 (Souza, 2011).

6 Nos seus mais de 100 anos de existência passou por diversas reestruturações desde que foi criada como Escola de Aprendizes e Artífices (1909 a 1937), passando a ser denominada Liceu Industrial de São Paulo (1937-1942), Escola Industrial de São Paulo (1942-1965), Escola Técnica Federal de São Paulo (1965-1999), Centro Federal de Educação Tecnológica de São Paulo-CEFET (1999-2008) e por fim, Instituto Federal de Educação, Ciência e Tecnologia de São Paulo-IFSP, de 2008 até o presente momento.

7 Esta rede expandiu-se vertiginosamente a partir de 2006 e atualmente conta com 40 unidades no estado. Entretanto, este crescimento na rede não gerou aumento da oferta de ensino médio, pelo contrário, o número de vagas diminuiu, perfazendo 1.217 vagas em 2012.Isso significa que a rede federal cresceu no estado de São Paulo priorizando sobretudo a oferta de cursos técnicos concomitantes e subsequentes.

8 Entre 1991 e 1992 o estado de São Paulo tinha 572 municípios, número que subiu para 625 entre 1993 e 1996, e para 645 em 1997.

9 Houve uma diminuição significativa nas taxas de reprovação entre 1995 e 1998, induzida pelos estímulos criados pela política pública estadual, tais como a criação das atividades para compensação de faltas dos alunos e o Programa de Recuperação nas Férias. Entretanto, em 2000 as taxas de reprovação voltaram a crescer, sugerindo que a redução das reprovações pode ter ocorrido de forma pontual em razão de políticas muito específicas. Já as taxas de abandono tiveram uma redução progressiva revelando tendência mais consistente, de modo que no ano de 2002, o abandono, que sempre foi superior à reprovação, começou a manter-se em patamares inferiores. A tendência de diminuição do abandono escolar em São Paulo antecipou-se ao restante do país. Porém, a reprovação seguiu caminho contrário. As taxas paulistas, que já eram melhores do que as nacionais no início dos anos 1990, apresentaram crescimento no fim da década, o que se confirmou em anos posteriores à série histórica aqui analisada. Em 2007 a taxa de reprovação do Ensino Médio em São Paulo foi de $15 \%$, e em 2010 , de $12,6 \%$.

10 Sposito revela que, em 1953 o curso ginasial concentrava cerca de 47,6\% de suas matrículas no período noturno (Sposito, 1984).

11 Parte deste processo foi registrado no caderno O caminho da escola. Luta popular pela escola pública, publicado pelo CEDI em 1986, e que descreve a luta pela criação do ensino de $2^{\circ}$ grau noturno na zona leste da cidade de São Paulo.

12 Refiro-me à escola de $1^{\circ}$ grau de oito anos, criada pela LDB 5.692/71, à qual a rede física paulista teve que se adequar modificando o modelo anterior de separação entre os grupos escolares, em que funcionava o primário, e os ginásios, em que funcionava o secundário.

13 A implantação da matrícula automática em 1998, pela SEE-SP, pode ter colaborado nesse sentido. Ao completar o ensino fundamental os alunos eram 
automaticamente matriculados na escola de ensino fundamental da rede municipal, ou estadual, mais próxima de sua residência, e que tivesse vaga. Isso pode ter reduzido a evasão de alunos nesta passagem para o ensino médio.

14 Trata-se de uma situação que resulta das tendências demográficas brasileiras caracterizadas pela queda da fecundidade e da mortalidade, fenômeno que vai se fazendo sentir através de ondas sucessivas que, a cada década, vai engrossando as faixas etárias seguintes (Madeira; Bercovich, 1992).

15 A rigor, foi uma ampliação da política de ciclos, pois o estado de São Paulo já havia implantando, desde 1983, gestão do governador Franco Montoro, o ciclo básico nas séries iniciais do $1^{\circ}$ grau, que consistiu na eliminação da reprovação entre a $1^{\mathrm{a}} \mathrm{e} 2^{\mathrm{a}}$ séries, formando uma única etapa. Foi a primeira política de ciclos implantada no estado, e vigorou até 1995. Sobre o assunto, consultar Barretto e Mitrulis (2001) e Souza (2004).

16 Esta constatação foi feita com base na análise dos jornais do período, que consiste numa das partes desta pesquisa.

\section{Referências}

ALMEIDA, Laurinda Ramalho de. O Projeto Noturno: incursões no vivido por educadores e alunos de escolas públicas paulistas que tentaram um jeito novo de caminhar. 1992. Tese (Doutorado em Educação) - Pontifícia Universidade Católica de São Paulo, São Paulo, 1992.

BARRETTO, Elba de Sá; MITRULIS, Eleni. Trajetória e desafios dos ciclos escolares no País. Estudos Avançados, São Paulo, v. 15, n. 42, p. 103-140, 2001.

BARRETTO, Elba de Sá; SOUSA, Sandra Zákia. Estudos sobre ciclos e progressão escolar no Brasil: uma revisão. Educação e Pesquisa, São Paulo, v. 30, n. 1, p. 1130, jan./abr. 2004.

BEISIEGEL, Celso. A Qualidade do Ensino na Escola Pública. Brasília: Liber, 2006.

BEISIEGEL, Celso. Estado e Educação Popular. Brasília: Líber, 2004.

CARVALHO, Célia Pezzolo de. Alternativas metodológicas para o trabalho pedagógico voltado ao curso noturno. Série Idéias. n. 25. São Paulo: FDE, 1998. P. 75-89.

CENTRO ECUMÊNICO DE DOCUMENTAÇÃO E INFORMAÇÃO. O Caminho da Escola. Luta popular pela escola pública. CEDI: São Paulo, 1986.

CORROCHANO, Maria Carla; NAKANO, Marilena. Jovens, Mundo do Trabalho e Escola. In: SPOSITO, Marília Pontes (Org.). Juventude e Escolarização. Brasília: MEC/Inep/Comped, 2002. P. 95-133.

DI PIERRO, Maria Clara; ANDRADE, Marcia Regina. Escolarização em assentamentos no estado de São Paulo: uma análise da Pesquisa Nacional de Educação na Reforma Agrária 2004. Revista Brasileira de Educação, Rio de Janeiro, v. 14, n. 41, p. 246-257, maio/ago. 2009.

FANFANI, Emilio Tenti. La Escuela y Lacuestión Social. Ensayos de sociologia de La educación. Buenos Aires: Siglo XXI Editores, 2007.

MACHADO, Maria Margarida. Estado da Arte da Produção Acadêmica sobre Ensino Médio no Brasil - Período de 1998 a 2008. Relatório Geral. Goiânia: MEC/UFG, abr. 2009. 
MADEIRA, Felicia; BERCOVICH, Alicia. A Onda Jovem e o seu Impacto na População Economicamente Ativa Masculina em São Paulo. Revista de Planejamento de Políticas Públicas, Rio de Janeiro, IPEA, n. 8, 1992.

OLIVEIRA, Romualdo Portela de. Da Universalização do Ensino Fundamental ao Desafio da Qualidade: uma análise histórica. Educação e Sociedade, Campinas, v. 28, n. 100 - Especial, p. 661-690, out. 2007.

PEREGRINO, Monica. Os Estudos Sobre Jovens na Intersecção da Escola com o Mundo do Trabalho. In: SPOSITO, Marília Pontes (Org.). Estado da Arte Sobre Juventude na Pós-Graduação Brasileira: Educação, Ciências Sociais e Serviço Social (1999-2006). Belo Horizonte: Argvmentvm, 2009. P. 87-120.

PINTO, José Marcelino de Resende. Ensino Médio. In: OLIVEIRA, Romualdo Luiz Portela; ADRIÃO, Thereza (Org.). Organização do Ensino no Brasil: níveis e modalidades na Constituição Federal e na LDB. São Paulo: Xamã, 2002.

ROMANELLI, Otaíza de Oliveira. História da Educação no Brasil. Rio de Janeiro: Vozes, 1997.

SPOSITO, Marilia Pontes. O Povo Vai à Escola - a luta popular pela expansão do ensino público em São Paulo. São Paulo: Edições Loyola, 1984.

SPOSITO, Marilia Pontes. Juventude e Escolarização. Brasília: MEC/INEP/ Comped, 2002.

WEBER, Max. Economia e Sociedade. Fundamentos da sociologia compreensiva. Volume. 2. Brasília: Editora da Universidade de Brasília São Paulo: Imprensa Oficial do Estado, 1999.

ZIBAS, Dagmar. A Escola Pública e a Escola Privada Diante das Propostas de Modernização do Ensino Médio. 1995. Tese (Doutorado em Educação) - Faculdade de Educação, Universidade de São Paulo, São Paulo, 1995.

ZIBAS, Dagmar; FRANCO, Maria Laura Puglisi Barbosa. Diagnóstico Quantitativo do Ensino Médio no Brasil. São Paulo: Fundação Carlos Chagas, 1997.

Ana Paula Corti é socióloga, professora do Instituto Federal de Educação, Ciência e Tecnologia de São Paulo-IFSP, desenvolve pesquisas em sociologia da educação e políticas educacionais.

E-mail: anapaulacorti@gmail.com 